\section{First results on early post-fire succession in an Abies cephalonica forest (Parnitha National Park, Greece)}

\author{
Petros Ganatsas ${ }^{(1)}$, Evangelia Daskalakou ${ }^{(2)}$, Despina Paitaridou ${ }^{(3)}$
}

Due to climate changes, the interest in the post-fire recovery of forest communities not adapted to wildfires, such as Greek fir (Abies cephalonica) forests, has increased. In this study, the post-fire recovery of the burned $A$. cephalonica forest of Parnitha National Park (central Greece) was investigated after a stand-replacing fire occurred in summer 2007 , as well as the performance of $A$. cephalonica plantings in the post-fire conditions. The research focused on the estimation of the $A$. cephalonica stand reproductive capacity without fire, the evaluation of the post-fire regeneration of the burned stands, and the monitoring of the plantations performance after the fire in the area. Then, based on the field and laboratory data, the post-fire recovery process of $A$. cephalonica was evaluated by application of a simplified form of the comprehensive causal framework for ecological succession estimation in open site, developed by Pickett et al. (1987), adapted to the study conditions. According to the findings of the study, stand seed crop without fire was high, while seed quality was found extremely low. In the burned area, no $A$. cephalonica seedling recruitment was observed during the three years after the fire. A. cephalonica plantings exhibited a medium overall survival rate $(65.3 \%)$, while seedlings growth was very slow. Thus, we can suppose that an ecological succession process may occur in the burned area, if no human interventions applied, and species adapted to wildfires (mainly shrubs and herbaceous) will dominate in the area. However, planting of $A$. cephalonica seedlings could contribute to the species participation in the post-fire communities.

Keywords: Greek fir, Ecological succession, Spontaneous regeneration, Planting performance

\section{Introduction}

The issue of post-fire ecology of forest communities has been studied extensively in several Mediterranean areas (Trabaud 1994 Agee 1998, Barbero et al. 1998, Ne'eman \&

(1) Aristotle University of Thessaloniki, Laboratory of Silviculture, PO Box 262, GR 54124, Thessaloniki (Greece); (2) Institute of Mediterranean Forest Ecosystems \& Forest Products Technology, NAGREF, Athens (Greece); (3) Development \& Forest Protection \& Natural Environment, Section of Forest Nurseries \& Seed Production MRDF, Athens (Greece)

\section{@ Petros Ganatsas (pgana@for.auth.gr)}

Received: Sep 14, 2011 - Accepted: Nov 09, 2011

Citation: Ganatsas P, Daskalakou E, Paitaridou D, 2012. First results on early post-fire succession in an Abies cephalonica forest (Parnitha National Park, Greece). iForest 5: 6-12 [online 2012-02-06] URL: http://www.sisef.it/iforest/contents/? id=ifor $0600-008$
Trabaud 2000). In most cases, the post-fire tree communities are made up with the same tree species as before fire due to their adaptation strategies to fire (Arnan et al. 2007). However, not all Mediterranean tree species have developed strategies to survive fire, and some species may disappear after fire (Retana et al. 2002, Rodrigo et al. 2004, Arnan et al. 2007). In recent years, extensive forest fires occured in forest ecosystems that have not developed efficient mechanisms of adjustment to wildfires (Retana et al. 2002). Common examples in the Mediterranean basin are the coniferous forests of Pinus nigra Arnold, Pinus silvestris L., Abies cephalonica Loudon, and Abies borisii regis Matf. The dominant species of these forests are obligate seeders, while the seeds produced ripen in autumn (Politi et al. 2011); thus, in the event of fire in the summer, there are no mature seeds to ensure regeneration. As a result, when they are burned, there is an increased risk of non-potential re-establishment of the burned forest due to regeneration failure, and burned forests are likely to turn into scrublands.

Taking into consideration the different scenarios of climate change (e.g., global warming, extreme weather events, heat waves, droughts, etc.), the problem of fire damages on these non-adapted ecosystems becomes even more urgent, as more fires are expected to occur (IPCC 2001, Chen et al. 2009, Politi et al. 2009). The expected increasing frequency of fires in mountain areas of the sub-Mediterranean zone in Mediterranean region, is estimated to play an important role in the ecosystems' distribution on this part of the world, and some important changes to forest vegetation are possible (Rodrigo et al. 2004, Arnan et al. 2007, Chen et al. 2009). For example, an ecological secondary succession and emergence of non-forest ecosystems (e.g., shrublands) was observed in many cases of burned pine forests not adapted to fire, after stand-replacing fires (Retana et al. 2002, Ocak et al. 2007). Alteration of forest ecosystems of $P$. nigra and $P$. silvestris to other ecosystems were also reported by Rodrigo et al. (2004) and (Arnan et al. 2007). Lack of autosuccessions after fire has been recently reported on Pinus halepensis forests, mainly after fire reoccurrence (Eugenio \& Lloret 2004, Pausas et al. 2004, De Luis et al. 2006) due to the short interval of fire return that does not allow $P$. halepensis to produce mature seeds.

In particular for Greece, there is a great scarcity of available data. Fyllas et al. (2007) reported for Mytilene that 13 years after fire in a forest of $P$. nigra, the burned area is dominated by mixed stands of Pinus brutia and broadleaf evergreen vegetation. Few studies with preliminary data reported that the post-fire natural regeneration of $\mathrm{A}$. $\mathrm{Ce}$ phalonica is absent (Ganatsas et al. 2009, Arianoutsou et al. 2010), while foresters report on several locations, covered by fir forests before fires, currently charaterized by low vegetation and called "Bare rocks" or "Bare mountain".

Several research efforts were launched in last years in the Mediterranean region in order to identify post-fire ecology of Mediterranean mountain pines, especially $P$. nigra (Cracia et al. 2002, Retana et al. 2002, Ordonez et al. 2005, Ordonez et al. 2006), while Espelta et al. (2003) focused on the reforestation methods of burned forests. On the contrary, studies on post-fire ecology of other Mediterranean forest species not adapted to fire, such as A. cephalonica, are extremely limited. Thus, the issue of post-fire recovery of burned forests of $A$. cephalonica, an endemic tree species not adapted to fire, is of great importance for the conservation of these important natural ecosystems, which provide multi-level benefits to the community, biodiversity and maintenance of flora and fauna.

The aim of the study was the estimation of the expected post-fire recovery of the burned 
Fig. 1 - Map showing the study area (red box) at the Mt.

Parnitha National Park, Greece.

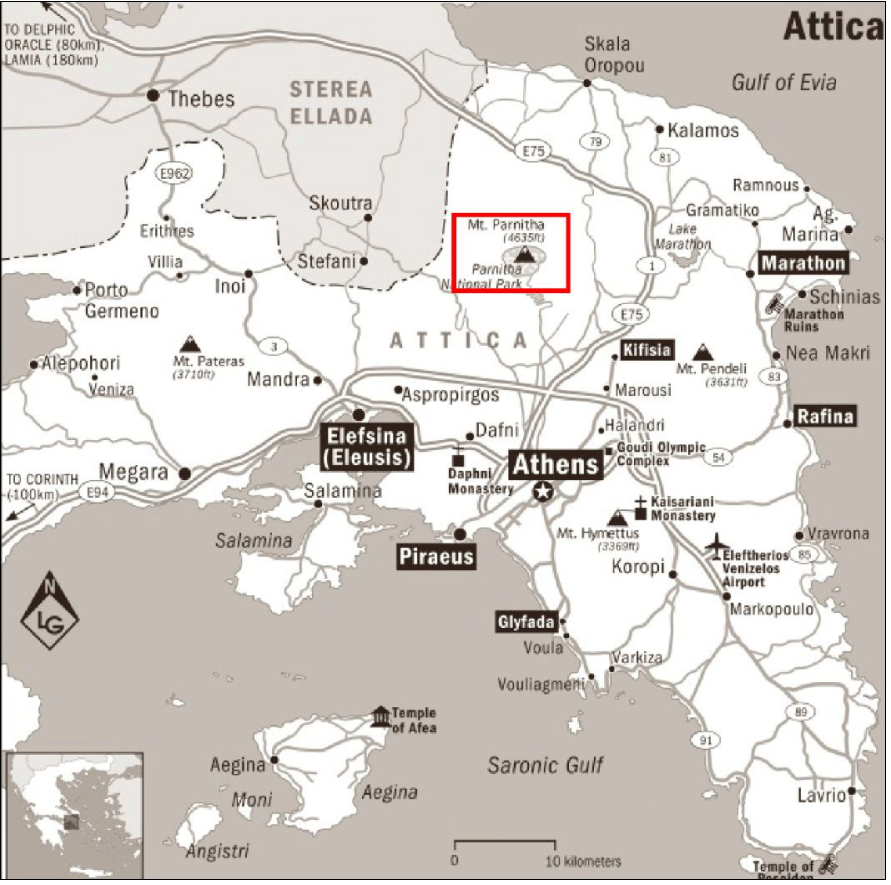

A. cephalonica forests of Parnitha National Park, central Greece. The specific objectives of the study were: (i) to achieve knowledge for the regeneration potential of the species in the area, which is considered a key element in assessing the ability of physical resettlement of the forest; (ii) the evaluation of the early post-fire behavior of the burned fir stands; and (iii) the estimation of the plantings performance in the burned area. Then, based on the analysis results, an evaluation of the post-fire recovery process in the burned area was carried out. To this aim, a simplified form of the general comprehensive framework for ecological succession in open site developed by Pickett et al. (1987) was applied, adapted to the study conditions and focused on $A$. cephalonica, in order to make a provision for the future status of the burned fir stands.

\section{Methods}

\section{Study area}

Mt. Parnitha National Park is one of the ten national parks in Greece, and is located in Attica, very close to the metropolitan city of Athens $(35 \mathrm{~km}$ northbound - Fig. 1). The National Park was established in 1961 for the conservation of flora and fauna of the area. A. cephalonica forest of this area consists of an important population of the species worldwide. The National Park has been included in Natura 2000 Network (GR 3000009) according to Habitats Directive (92/43/EEC), and it is also an important area for the protection of wild birds (SPA) according to Birds Directive (2009/147/EC). Mt. Parnitha is the largest mountain range in
Attica, central Greece, and its highest summit elevates up to $1413 \mathrm{~m}$ a.s.l. The bedrock consists of sedimentary rocks, mainly schist and limestone. Soils are generally infertile and shallow, apart from some karstic plateaus which are natural meadows with rich ground vegetation. The climate is considerably different from the rest of Attica; at
Unclassified

Agricultural Areas

Forests

Urban Fabrics / Bare soil Areas

Burnt Areas gery (Petropoulos et al. 2010).
$1000 \mathrm{~m}$ elevation, the average rainfall is 822 $\mathrm{mm}$, the annual snow level is $120 \mathrm{~cm}$, the average relative humidity is $77 \%$, the number of rainy days is 70 , of snowy days 33 , and the average annual temperature is $11^{\circ} \mathrm{C}$. The flora of the area is exceptionally rich, including 1093 plant species, 93 of which are Greek endemics (Aplada et al. 2007). Also, 42 out of 116 mammal species of the country have been recorded in this area, including rare, endangered, and protected species. Cervus elaphus formed a population of over 400 individuals before the fire.

Mt. Parnitha was a densely forested mountain, which in the lower zone was covered by forests of evergreen sclerophyllous shrubs and $P$. halepensis, while the higher slopes (above $800 \mathrm{~m}$ ) were covered by the unique forest of the endemic A. cephalonica. The National Park covers the central bulge of the mountain. The biggest part of the core $(90 \%)$ is covered by pure mature A. cephalonica stands; other common woody species participating in the forest vegetation are Juniperus oxycedrus and Quercus coccifera (Parnitha National Park 2007). In summer 2007, a catastrophic fire burned down 18957 ha (Fig. 2) of the A. cephalonica forest, 10562 ha of $P$. halepensis, and 3976 ha of evergreen broad-leaved shrublands. Whereas the $P$. halepensis forest is expected to get naturally regenerated (Daskalakou 1996, Thanos et al. 1996), it is doubtful whether the $A$. cephalonica forest can regenerate.
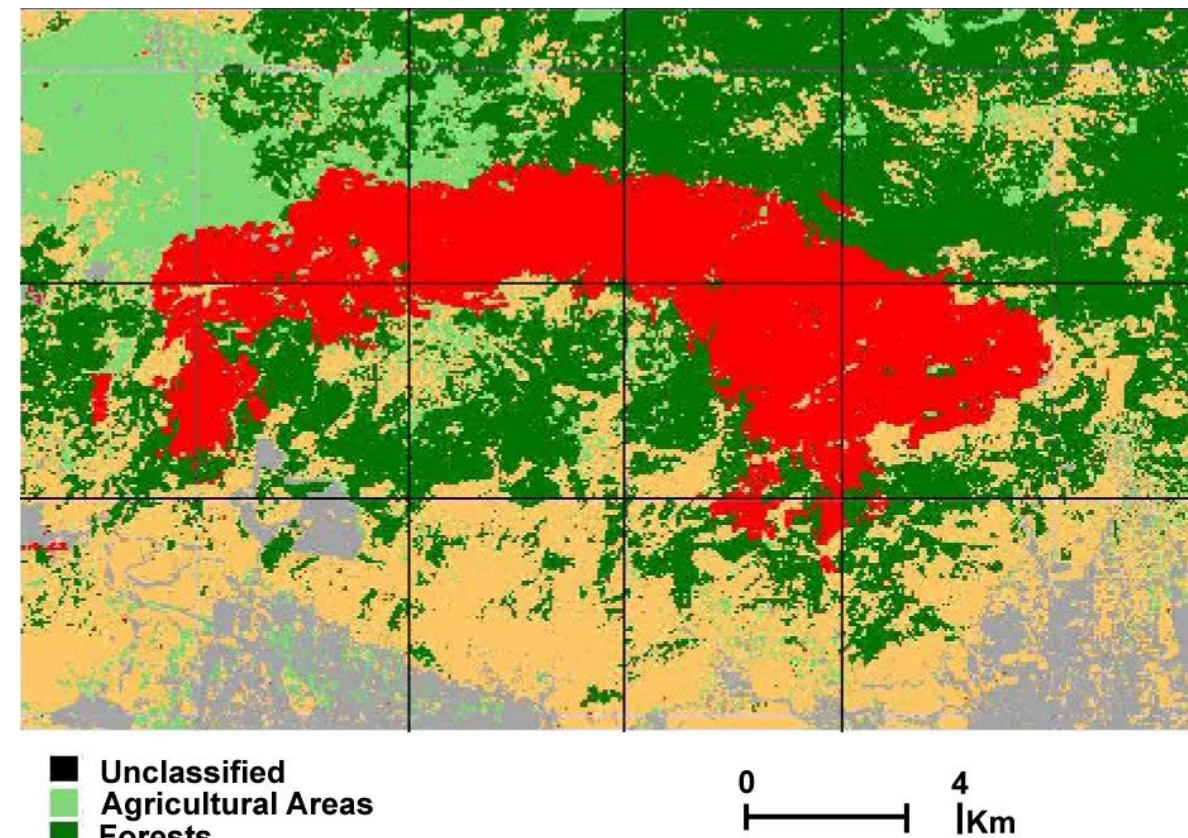

Scrubland / Herbaceous vegetation

Fig. 2 - Map of the burned area after classification, obtained from Landsat TM post-fire ima- 
Fig. 3 - Plantings of $A$. cephalonica seedlings in the burned area of Parnitha National Park. Shading was achieved through the use of sacking in a triangular shape, based on 3 canes around the plant, of approximately $50 \mathrm{~cm}$ in height, while the sacking had a height of about $30 \mathrm{~cm}$.

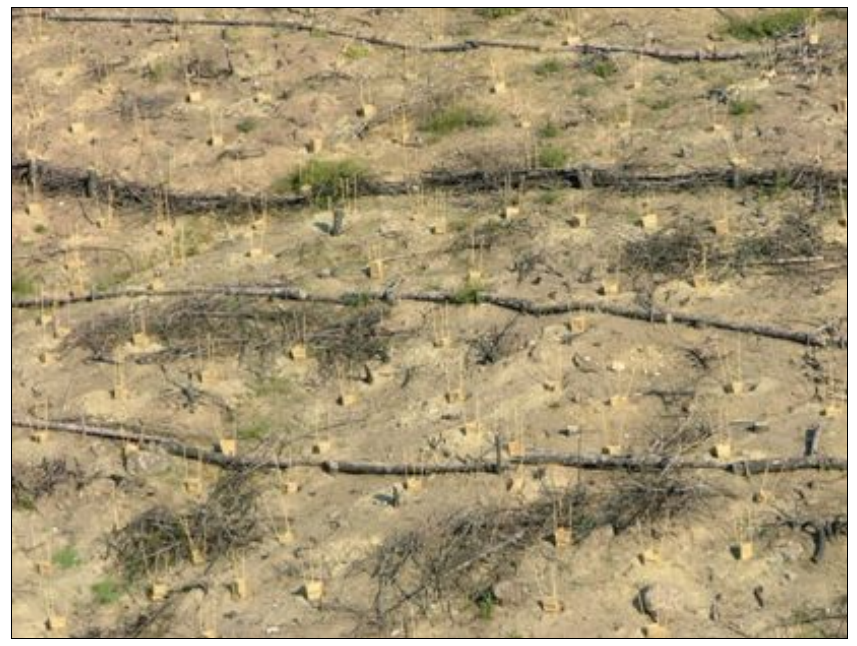

Assessment of the reproductive capacity of the A. cephalonica forest without the fire

Seed production of the unburned fir forest was evaluated through 4 permanent sampling plots $(25 \times 20 \mathrm{~m})$, randomly established in mature fir stands. In each plot, all fir trees were counted, as well as the number of the individuals bearing at least one cone. Consecutively, a cone count was made visually on 10 randomly-chosen individuals (bearing cones) per plot. The quantity (number) of seeds per cone was recorded in 60 randomly selected cones. The total number of seeds per ha was calculated as the number of trees bearing cones per ha $x$ the number of cones per tree $x$ the average number of seeds per cone.

The above measurements were carried out twice, in 2007 (the year of the fire), and in 2010 (3 years after fire). Both years were characterized by a quite large cone production. Seed quality was estimated by the ap plication of a wide project of seed collection from the area, for three consecutive years (2007, 2008 and 2009), that took place under the supervision of the Reforestation $\mathrm{Di}$ rectorate, Region of Attica and the Management Authority of Parnitha's National Park The Central Depository of Forest Seeds and the Laboratory of Seed Quality Control and Certification, (Directorate of Reforestation \& Watershed Management, Greek Ministry of Rural Development and Food) were responsible for all seed preparation, quality control and germination trials. Rules of the International Seed Testing Association (ISTA 2003) were applied in all seed process. Seed germination tests were carried out in Petri dishes with a sample of 100 seeds in 4 replications, after cold stratification for 28 days at $4{ }^{\circ} \mathrm{C}$. Petri dishes were placed in germination chamber of controlled conditions. The chamber's relative humidity was $95 \%$, the temperature $20{ }^{\circ} \mathrm{C}$, and the light exposure $16 / 8 \mathrm{~h}$ light/darkness. The germination control lasted for 4 weeks. At the end of the test period the final germination percentages of seeds were estimated.

\section{Post-fire behavior of the burned A. cephalonica stands}

Field data collection was performed for the evaluation of post-fire behavior of the burned $A$. cephalonica forest. Sampling was achieved in 5 transects established perpendicular to the fire limits in each of 5 different and representative areas of the mountain. The aim was to explore for any A. cephalonica seedling recruitment in the burned area during the early post-fire years, taking into consideration that any recruitment will probably occurs within the transition zone of 30 $\mathrm{m}$ from the unburned stands, since seeds are expected to be dispersed within this zone from the fire edge, namely the unburned tree canopy vertical projection points (zero point), and moving $20 \mathrm{~m}$ towards the unburned forest, a plot of $5 \times 5 \mathrm{~m}$ was established. Sequentially, moving towards the burnt area, three plots were taken at distances of 0,10 and $30 \mathrm{~m}$ from the zero point. Plots were permanently marked on the ground by wooden sticks and accurately localized by a GPS. A typical forest compass was used for the plot exposure description. For all sampling plots altitude, slope, and exposure were recorded.

The existing vegetation within the plots and the natural regeneration of $A$. cephalonica were recorded. In each plot we measured the following plant community parameters: vegetation composition, total plant cover, woody and herbaceous species cover (according to Domin scale of cover/abundance), and dominant plant height (Ganatsas et al. 2011). Herbaceous species were identified at the family level, while for woody species at the species level. Mean dominant height was estimated by measuring the five tallest individuals of each plant species per plot (Buford \& Burkhart 1987, Ganatsas et al. 2011). Measurements of $A$. cephalonica na(Panetsos 1975). In each transect, beginning tural regeneration included the number of seedlings per plot, and the height of all seedlings. Measurements were taken in November 2007 (after first post-fire summer), and repeated in July 2008 (one year after fire), and in May 2010 (approximately 3 years after fire).

\section{Plantings performance}

Plantings were carried out in selected burned sites after a detailed study and mapping of the site conditions in the burned area. Due to the unfavorable environmental conditions for the re-establishment of $A$. cephalonica, namely extremely low soil depth on hard limestones characterized by fast drainage, the best locations of the area were selected for planting in order to avoid any failure. It is noteworthy to mention that, the Reforestation Programme of the burned forest ("Reforestation Tasks Programming of Parnitha National Park (2007-2013)" concerns less than $50 \%$ ( $9457.8 \mathrm{ha}$ ) of the total burnt fir forest. The remaining burned area of 10000 ha, though formerly covered by fir forests, has been considered as unfavorable for any kind of reforestation effort due to "unsuitable substrate" (Geomelas et al. 2007). The plantings were carried out in the spring of 2008. Three year-old containerized seedlings of $A$. cephalonica from Peloponnesus provenance (Vitina area, southern Greece) were manually planted in pits, spaced approximately $2 \times 3 \mathrm{~m}$ (Geomelas et al. 2007). To protect seedlings from direct solar radiation during summer, artificial shading was provided using sacking in a triangular shape, based on 3 canes around the plant, of approximately $50 \mathrm{~cm}$ in height, while the sacking had a height of about 30 cm (Fig. 3).

Three planting locations were randomly selected for monitoring. In each location 50 fir seedlings were randomly marked and labeled. For each seedling height, survival, the planting method, and the shading type were recorded. Monitoring was carried out in July 2008 (before summer drought), in October 2008 (after summer period), in May 2009 and May 2010. Finally, the seedling survival rate, the average annual height growth, and the success of the shading were assessed.

Evaluation of post-fire ecological succession process

Post-fire ecological succession of the burned $A$. cephalonica forest was evaluated based on analysis of the collected data, and using a simplified form of the comprehensive causal framework of Pickett et al. (1987), adapted to the study conditions, and focused on $A$. cephalonica. All the collected field and laboratory data for the area were used to adapt the general model to the specific ecological conditions. This framework concerns the succession in open sites and 
Tab. 1 - Cone and seed production of the A. cephalonica stands in Parnitha National Park, in the years 2007 and 2010 (both heavy cone crop years). Values are mean and standard error of mean (in parenthesis). Values in the same line followed by different letters are significantly different.

\begin{tabular}{|c|c|c|c|c|c|c|c|c|}
\hline \multirow[t]{2}{*}{ Plot } & \multirow{2}{*}{$\begin{array}{l}\text { Trees } \\
\text { per ha }\end{array}$} & \multicolumn{2}{|c|}{$\begin{array}{c}\text { Trees bearing } \\
\text { cones }(\%)\end{array}$} & \multicolumn{2}{|c|}{ Cones per tree } & \multirow{2}{*}{$\begin{array}{c}\text { Average } \\
\text { seeds per } \\
\text { cone }\end{array}$} & \multicolumn{2}{|c|}{ Seed crop per ha } \\
\hline & & 2007 & 2010 & 2007 & 2010 & & 2007 & 2010 \\
\hline 1 & 760 & 78.9 & 88.9 & $28.5(3.3)$ & $14.0(2.0)$ & - & 2941.144 & 1627.887 \\
\hline 2 & 1000 & 60 & 71.4 & $29.1(3.5)$ & $21.7(2.7)$ & - & 3004.866 & 2666.483 \\
\hline 3 & 580 & 58.6 & 66.7 & $19.9(2.2)$ & $22.7(2.4)$ & 172.1 & 1164.017 & 1511.334 \\
\hline 4 & 1240 & 75.8 & 80 & $26.4(2.9)$ & $15.9(2.5)$ & - & 4270.470 & 2714.499 \\
\hline Average & 895 & $68.3^{\mathrm{b}}$ & $76.7^{\mathrm{a}}$ & $26.0(2.5)^{\mathrm{a}}$ & $18.6(2.1)^{b}$ & (12.3) & $2735.255^{\mathrm{a}}$ & $2130.051^{b}$ \\
\hline
\end{tabular}

Tab. 2 - Seed characteristics of A. cephalonica collected in Parnitha National Park. Values are mean and standard error of mean (in parenthesis). Values in the same column followed by different letters are significantly different. $\left({ }^{*}\right)$ : Clearness difference is due to the improved ginning conditions.

\begin{tabular}{cccccc}
\hline $\begin{array}{c}\text { Collection } \\
\text { year }\end{array}$ & $\begin{array}{c}\text { Amount of } \\
\text { seeds } \\
\text { collected (kg) }\end{array}$ & Clearness* $^{*}$ & $\begin{array}{c}\text { Weight of } \\
\mathbf{1 0 0 0} \text { seeds (g) }\end{array}$ & $\begin{array}{c}\text { Seeds } \\
\text { per kg }\end{array}$ & $\begin{array}{c}\text { Mean } \\
\text { germination } \\
\text { (\%) }\end{array}$ \\
\hline 2007 & 31 & 76.2 & $44.195(0.85)^{\mathrm{b}}$ & $22.627(435.2)^{\mathrm{b}}$ & $17.2(2.28)^{\mathrm{a}}$ \\
2008 & 34 & 95.1 & $48.753(0.55)^{\mathrm{a}}$ & $20.512(231.4)^{\mathrm{c}}$ & $13.2(1.03)^{\mathrm{b}}$ \\
2009 & 2 & 98 & $39.049(0.83)^{\mathrm{c}}$ & $25.609(544.3)^{\mathrm{a}}$ & $1.7(0.47)^{\mathrm{c}}$ \\
\hline
\end{tabular}

Tab. 3 - Woody species ground cover, and height in burned fir forest in Parnitha National Park, three years after fire. Values are mean and standard error of mean (in parenthesis).

\begin{tabular}{lcc}
\hline Species & $\begin{array}{c}\text { Ground cover } \\
\text { (\%) }\end{array}$ & $\begin{array}{c}\text { Height } \\
\text { (cm) }\end{array}$ \\
\hline Quercus coccifera & $14.5(5.1)$ & $51.8(3.7)$ \\
Phillyrea latifolia & $3.5(1.5)$ & $41.3(3.8)$ \\
Rubus hirtus & $1.9(1.2)$ & $38.6(4.5)$ \\
Asparagus acutifolius & $0.7(0.3)$ & $31.1(2.6)$ \\
Cistus creticus & $1.6(1.3)$ & $38.0(1.2)$ \\
Quercus pubescens & $0.1(0.1)$ & $17.2(2.5)$ \\
Total Woody species cover & $22.2(3.8)$ & - \\
Herb and grass species cover & $14.9(2.6)$ & - \\
Total plant cover & $37.1(3.5)$ & - \\
\hline
\end{tabular}

was developed based on classical causes of succession, aiming at comprehensiveness, and specific mechanisms nested within more general causes. It considers the basic ideas of succession such as pathways, mechanisms, and models. It starts the mechanistic hierarchy at a general level by asking "What causes succession?", then asks "What interactions, processes or conditions contribute to the general causes of succession?", and at the third and most detailed level encompasses site-specific factors or behaviors that determine the interactions of the plants and other organisms affecting them. These interactions are the essence of succession and are responsible for the great variety in the succession. The specific features of the framework are quantified and incorporated into the flow model of MacMahon (1980). The model can be used to predict species replacement patterns and associated community level phenomena (Pickett et al. 1987).

\section{Statistical analysis}

One-way standard ANOVA method was used to test differences. Duncan's test was used to compare the mean values of cones per tree and seed crops between the two collection years, seed weight among the three collection years, and planted seedling height and survival among the three plots. All statistical analyses were carried out using a critical threshold of $\alpha \leq 0.05$.

\section{Results}

Reproductive capacity of A. cephalonica forest without the fire factor

In mature unburned fir stands, the percentage of trees bearing cones in 2007 was significantly lower than that of $2010(68.3 \%$ and $76.7 \%$, respectively - Tab. 1). Cone production per tree greatly varied, ranging from 8 to 60 cones in 2007, and from 4 to 45 in 2010 , with an average value of 26.0 and 18.6 cones per tree, respectively. Moreover, a great variation of seed number per cone was noted, which ranged between 75 and 278 seeds per cone, with an average of 172.1 . This number does not include infertile and immature seeds. Seed production was 2735255 seeds per hectare in 2007, and significantly lower $(2130051)$ in 2010. These figures are fairly large to secure forest natural regeneration, though were recorded in masting years and mature stands.

The average weight of $A$. cephalonica seed ranged between 0.039 in 2009 to $0.048 \mathrm{~g}$ in 2008 , and significantly differed between the three years (Tab. 2). Seed germination in the laboratory was found extremely low and significantly differed between the three years $(17.2 \%$ in $2007,13.2 \%$ in 2008 and only $1.7 \%$ in 2009). Thus, despite the high seed production in the studied years, the species natural regeneration in the field was found very low, due to extremely low germination capacity of seeds. Seedling density in the unburned stands was found particularly poor $\left(0.08\right.$ seedlings $\left.\mathrm{m}^{-2}\right)$ and ranged between 0 and 0.24 seedlings per $\mathrm{m}^{2}$. The extremely unfavorable site conditions for species natural regeneration also contributed to these low values.

Post-fire behavior of the burned A. cephalonica stands

According to all samplings, no A. cephalonica seedlings were found in the burned area, even if proximal to unburned stands, confirming that $A$. cephalonica natural regeneration in an open post-fire environment seems rather unlikely. Although no information is available for soil seed bank, seed dispersal in the transition zone with unburned stands (approx. $30 \mathrm{~m}$ ) was expected. Since no seedling emergence was observed in any plots, seed germination in the post-fire conditions, under the absence of shading, should be considered the key point. Germination failure in the field may be either due to their low quality or to the absence of a favorable seedbed in the post-fire conditions.

Generally, the post-fire plant community recovery was very slow, especially on rocky limestone slopes and on soils of poor site quality. Three years after fire, our results show that the pre-fire dominant tree species (A. cephalonica) was completely absent in the post-fire conditions, in all sampling plots during the three years of monitoring (Tab. 3 ). Furthermore, only a few woody plant species were recorded in the post-fire conditions, like Quercus coccifera that seems to be the dominant woody species in post-fire communities in most cases, and sparsely Phillyrea latifolia, Rubus hirtus, Quercus pubescens, Asparagus acutifolius and Cistus creticus in the lower altitudes. However, only $Q$. coccifera cover exceeded the threshold of $5 \%$. 
Tab. 4 - Survival and growth characteristics of planted A. cephalonica seedlings (Vytina provenance) in Parnitha National Park, one and two years after planting. Values are mean and standard error of mean (in parentheses). Values in the same column followed by different letters are significantly different; (ns): not significant.

\begin{tabular}{lccccccc}
\hline & \multicolumn{9}{c}{$\mathbf{2 0 0 9}$} & \multicolumn{2}{c}{$\mathbf{2 0 1 0}$} \\
\cline { 3 - 8 } \multicolumn{1}{c}{ Location } & $\mathbf{n}$ & $\begin{array}{c}\text { Seedling } \\
\text { survival } \\
(\%)\end{array}$ & $\begin{array}{c}\text { Mean } \\
\text { height } \mathbf{~ c m} \\
( \pm \text { SE) }\end{array}$ & $\begin{array}{c}\text { Shading } \\
\text { type }\end{array}$ & $\begin{array}{c}\text { Shading } \\
\text { preserva- } \\
\text { tion }(\%)\end{array}$ & $\begin{array}{c}\text { Seedling } \\
\text { survival } \\
(\%)\end{array}$ & $\begin{array}{c}\text { Mean } \\
\text { height cm } \\
( \pm \text { SE) }\end{array}$ \\
\hline Mavrovouni & 50 & $94.0^{\text {ns }}$ & $14.7(0.2)^{\mathrm{a}}$ & sacking & 0 & $75.0^{\mathrm{b}}$ & $21.3(0.3)^{\mathrm{b}}$ \\
Viliani & 50 & $96.0^{\text {ns }}$ & $13.5(0.1)^{\mathrm{b}}$ & - & 0 & $33.0^{\mathrm{c}}$ & $15.8(0.4)^{\mathrm{c}}$ \\
Gaidourovrisi & 50 & $100.0^{\text {ns }}$ & $14.2(0.2)^{\mathrm{ab}}$ & no & - & $88.0^{\mathrm{a}}$ & $26.4(0.3)^{\mathrm{a}}$ \\
Average & - & $96.7(1.8)$ & $14.1(0.1)$ & - & - & $65.3(16.6)$ & $21.2(0.3)$ \\
\hline
\end{tabular}

\section{Plantings performance}

A. cephalonica seedling survival was very high $(96.7 \%)$ one year after planting (Tab. $4)$. It should be noted that the selected locations for planting were the most favorable (mainly northern aspects with sufficient soil depth for plant growth), so as to ensure seedling establishment, whereas 10 waterings were done during the first summer period. Artificial shading seems not to be the crucial factor for seedlings performance since no survival and growth differences were found between shaded and not shaded seedlings (Tab. 4). Moreover, shading construction was destroyed in almost all cases after the first post-fire winter due to snow and wind damages. Two years after plantings, the survival of the planted seedlings differentiated among plots: in the second plot, located in southern aspect, the survival rate strongly decreased $(33 \%)$, while in the other two plots the survival rate remained significantly high $(75 \%$ and $88 \%)$. Nevertheless, the overall survival rate was $65.3 \%$, which means that during the second year, the average seedlings' mortality was $31.4 \%$, compared to
$3.3 \%$ during the first post-planting year. Seedlings growth was relatively slow: the mean seedlings' height reached 14.1 and $21.2 \mathrm{~cm}$, one and two years after planting, respectively. The observed low growth creates doubts on the further planting evolution, considering the general endogenous slowthe juvenile period.

Post-fire succession process in the burned A. cephalonica forest

According to the findings of this study, no A. cephalonica seedling recruitment was observed in the burned area for the three years after fire. This means that at this initial stage (Capitanio \& Carcaillet 2008) A. cephalonica is absent from post-fire community. However, in the case of a later successful establishment of a post-fire wave of the $A$. cephalonica during a possible favorable year, this is anticipated within the transition zone of $30 \mathrm{~m}$ from the unburned stands. In the rest burned area, due to the absence of $A$. cephalonica (the dominant pre-fire tree species) in the vegetation composition, we may growing development of the species during hypothesize that an ecological succession process may occur.

If we apply the results of our analysis to the general comprehensive casual framework suggested by Pickett et al. (1987) for ecological succession in open site, the recovery of the burned fir community may follow the diagram of Fig. 4 (after simplification of the model described by Pickett et al. (1987). A large open site was created in the area after the stand-replacing fire that comprises the first (initial) stage (stage $S O$ ) after disturbance. Based on the field observation, no surviving fir trees were observed in the burned area and no individuals or groups of trees managed to survive.

Three years after fire, no $A$. cephalonica seedlings were found even in the plots closer to the unburned stands. This suggests that the first post-fire community (stage $S 1$ ) is characterized by the absence of the pre-fire dominant species $A$. cephalonica.

The next post-fire communities at the stage $S 2$ described by Pickett et al. may also be characterized by the absence of pre-fire dominant species $A$. cephalonica due to the following reasons. First, the environmental conditions are very harsh for the re-establishment of $A$. cephalonica because of: (i) the hard limestones which are characterized by the quick drainage, and the extremely low soil depth; (ii) the relative low elevation of the area (max $1413 \mathrm{~m}$ a.s.l.) that may cause further problems in seedling recruitment of A. cephalonica (Politi et al. 2009); (iii) the post-fire environment that is characterized by: (a) the absence of organic matter (due to the burning), which was found to be among the most explanatory variables for seedling emergence (Stamatopoulos 1995); and (b) the fully sunlight slopes with no protection for the young seedlings. All the above

Fig. 4 - Simplified model of the post-fire succession process, based on the general causal framework of Pickett et al. (1987), after MacMahon (1980), adapted to the burned A. cephalonica forest of Parnitha National Park, Attica, central Greece. 
factors may hamper seedling recruitment of A. cephalonica. Moreover, the migration capacity of the species, which is an obligate seeder, is very low, since seed dispersal capacity is restricted to less than $30 \mathrm{~m}$ (Panetsos 1975). Additional problems are caused by the observed low quality of seeds. The low vitality and ageing of parent fir trees favors secondary attacks by insects and diseases, thus, many fir trees died every year (Tsopelas et al. 2004, Parnitha National Park 2007). The parasitic species Viscum album, the bark insect Gryphalus piceae and the insect Choristoneura murinana, attacking buds and new needles, play an important role in fir forest decline, also affecting species' regeneration. Herbivory also might negatively affect seedling development, since consumption of few young seedlings has been observed by the quite large number of deer population in the area (personal observations). Therefore, we expect that other species showing better adaptation to postfire conditions will displace fir from dominance, like the resprouter shrub species Quercus coccifera (mainly) and Phillyrea latifolia found in the burned area (see Tab. 3 ), the seeder Cistus creticus, as well as many herb and grass species.

The aforementioned analysis also suggests that during the next successional stages any establishment of $A$. cephalonica in the open post-fire conditions is doubtful, and thus, the recovery to the pre-fire forest community ( $A$. cephalonica forests, stage $S 3$ ) is rather unlikely. This will offer the opportunity to other species, adapted to wildfires, to colonize the burned area. Plantings of $A$. cepha lonica could contribute to the species' participation in the future plant communities and the original forest re-establishment. However, there are some limiting factors: (i) the low endogenous growth rates of A. cepha lonica in the early stages of its life cycle; (ii) the absence of a forest canopy, since fir is a strong shade-demanding species; and (iii) the abovementioned harshness of site conditions, especially the extremely low soil depth.

\section{Discussion}

Based on the results of this study, it may be hyothesized that a natural re-establishment of the A. cephalonica forest in the burned area of the National Park is unlikely in the near future, since no seedlings were found in all field sampling during three years after fire. Moreover, based on the field observation, no adult $A$. cephalonica trees did survive in the burned area. The recolonization rate from unburned locations is expected to be very low since seed dispersal for fir is restricted to less than $30 \mathrm{~m}$. Furthermore, the observed low quality of seeds, in combination with the unfavorable site conditions (Geomelas et al. 2007), strongly reduces the possibility for seed germination and seedling recruitment. Very low seedling survival of naturally-regenerated $A$. cephalonica seedlings of was also found on Mt. Aenos, Cephalonia Island, western Greece (Politi et al. 2009). Additionally, natural regeneration of the species in the area faces many difficulties (Stamatopoulos 1995, Apatsidis et al. 2005), while the tree ageing may cause further problems for the recovery of the burned $A$. cephalonica stands (Tsopelas et al. 2004).

All the above evidences indicate that forests communities that have not efficiently adapted to fire (such as the A. cephalonica forests) seem to be unable to naturally recover in short time to the original community. Consequently, it is expected that other species will dominate the burned area. This may result in a secondary ecological succession of the burned forest, if no human interventions will be applied. Based on the field and laboratory data, as well as on the application of the simplified form of the comprehensive causal framework of Pickett et al. (1987), a number of significant factors leads the burned communities to follow a secondary succession towards a shrubland community, dominated by the woody species Quercus coccifera, Phillyrea latifolia, Rubus hirtus, Asparagus acutifolius and other less abundant shrub, herb and grass species. At lower altitudes the well adapted Cistus creticus will have a higher contribution in the community composition. However, the vegetation recovers at low rates and complete canopy closure will take long time. The burned area consists of slopes with strong to steep inclination, which in many cases are extremely sensitive to soil erosion (Geomelas et al. 2007).

Ecological secondary succession and emergence of non-forest ecosystems (e.g., shrublands) was observed in many cases in burned pine forests not adapted to fire, after standreplacing fires (Retana et al. 2002, Ocak et al. 2007, Fyllas et al. 2007). Changes of forest ecosystems of $P$. nigra and $P$. sylvestris to other ecosystems were also reported (Rodrigo et al. 2004, Arnan et al. 2007), while Chen et al. (2009) concluded that the increase of wildfires due to global change will promote hardwoods- instead of conifers-dominated biocoenoses.

Planting with $A$. cephalonica seedlings could contribute to species participation in the future plant communities and to the forest re-establishment in the burned area. However, this presents some uncertainties since seedling survival of the species ranged from low $(33 \%)$ in the southern aspect to relatively high ( $75 \%$ and $88 \%$, respectively) in better sites, and the recorded seedling growth was very slow. As for the reforestation activities carried out so far at Parnitha National Park, planting has been taken place in the most favorable sites (with enough soil depth), and seedlings were watered and shaded, so ensuring species establishment in the above locations. According to the Reforestation Plan for the area, the reforested area in the first year comprises $2.8 \%$ of the total burnt fir forest while the total estimated reforestation area accounts for about 4522.2 ha $(23.3 \%$ of the total burned A. cephalonica forest).

Based on the aforementioned analysis, the task of artificial re-establishment of the $A$. cephalonica forest by planting seems to be the key factor for species participation in the post-fire plant communities. Otherwise, low (shrub or herbaceous) plant communities will dominate the burned area. Successful planting of A. cephalonica seedlings is a very difficult operation which requires very careful and long-term planning. A. cephalonica is a shade-demanding species with a low growth rate during its early stages, making difficult its establishment after fire, even artificially. The sound site selection, adequate watering during summer, as well as the use of artificial shading, seem to constitute important factors for seedlings survival. Moreover, survived trees could play the important role in seed dispersal for the gradual re-establishment of $A$. cephalonica in next generations in the area of the National Park.

\section{Conclusions}

The inability of the A. cephalonica to regenerate naturally in post-fire conditions may lead to a secondary ecological succession to low (shrub or herbaceous) plant communities. The necessity of the conservation of biodiversity within the National Park enforces the need of artificial planting of $A$. cephalonica, a task that seems to be a difficult, requiring a very careful and long-term planning due to the species' ecophysiological demands and the harsh conditions of the site.

\section{Acknowledgements}

We thank G. Poulis, E., Kapsalis, V. Mendeli and G. Prassas, foresters, for their contribution in the field work, and Dr. Tsakaldimi Marianthi, for text editing.

\section{References}

Agee JK (1998). Fire and pine ecosystems. In: "Ecology and biogeography of Pinus" (Richardson DM ed). Cambridge University Press, Cambridge, UK, pp. 193-218

Apatsidis LD, Tsopelas P, Aggelopoulos E (2005). Silvicultural problems in the fir forest of Mount Parnis. Geotechnical Scientific Issues 16: 4-17 (in Greek).

Aplada E, Georgiadis T, Tiniakou A, Theocharopoulos M (2007). Phytogeography and ecological evaluation of the flora and vegetation of $\mathrm{Mt}$ Parnitha (Attica, Greece). Edinburgh Journal of Botany 64: 185-207. - doi: 10.1017/ S096042860700087X 
Arianoutsou M, Christopoulou A, Kazanis D, Tountas Th, Ganou E, Bazos I, Kokkoris Y (2010). Effects of fire on high altitude coniferous forests of Greece. In: "VI International Conference on Forest Fire Research 2010" (Viegas DX ed). Coimbra (Portugal) 15-18 November 2010.

Arnan X, Rodrigo A, Retana J (2007). Post-fire regeneration of mediterranean plant communities at a regional scale is dependent on vegetation type and dryness. Journal of Vegetation Science 18: 111-122. - doi: 10.1111/j.1654-1103.2007. tb02521.x

Barbero M, Loisel R, Quezel P, Richardson DM, Romane F (1998). Pines of the mediterranean basin. In: "Ecology and biogeography of Pinus" (Richardson DM ed). Cambridge University Press, Cambridge, UK, pp. 153-170.

Buford MA, Burkhart HE (1987). Genetic improvement effects on growth and yield of loblolly pine plantations. Forest Science 33: 707-724.

Capitanio R, Carcaillet C (2008). Post-fire mediterranean vegetation dynamics and diversity: a discussion of succession models. Forest Ecology and Management 255: 431-439. - doi: 10.1016/j. foreco.2007.09.010

Chen HYH, Vasiliauskas S, Kayahara GJ, Ilisson $\mathrm{T}$ (2009). Wildfire promotes broadleaves and species mixture in boreal forest. Forest Ecology and Management 257: 343-350. - doi: 10.1016/j. foreco.2008.09.022

Cracia M, Retana J, Roig P (2002). Mid-term successional patterns after fire of mixed pine-oak forests in NE Spain. Acta Oecologica 23: 405411. - doi: 10.1016/S1146-609X(02)01169-4 Daskalakou E (1996). Eco-physiology of the postfire regeneration of Aleppo pine (Pinus halepensis). Ph.D. Thesis, Department of Botany, Faculty of Biology, National Kapodistrian University of Athens, Greece, pp. 179.

De Luis M, Raventós J, González-Hidalgo JC (2006). Post-fire vegetation succession in Mediterranean gorse shrublands. Acta Oecologica 30: 54-61. - doi: 10.1016/j.actao.2006.01.005

Espelta JM, Retana J, Habrouk A (2003). An economic and ecological multi-criteria evaluation of reforestation methods to recover burned Pinus nigra forests in NE Spain. Forest Ecology and Management 180: 185-198. - doi: 10.1016/ S0378-1127(02)00599-6

Eugenio M, Lloret F (2004). Fire recurrence effects on the structure and composition of Mediterranean Pinus halepensis communities in Catalonia (northeaster Iberian Peninsula). Ecoscience 11: 446-454

Fyllas N, Phillips OL, Kunin WE, Matsinos YG, Troumbis AI (2007). Development and parameterization of a general forest gap dynamics simulator for the north-eastern Mediterranean basin
(Greek forest species). Ecological Modelling 204: 439-456. - doi: 10.1016/j.ecolmodel.2007. 02.006

Ganatsas P, Daskalakou E, Paitaridou D, Mendeli V, Prassas G (2009). Study on the post-fire rehabilitation capacity of the burned endemic fir forest in Parnitha National Park, Greece. In: Proceedings of the " $14^{\text {th }}$ Conference of the Hellenic forestry society". Patras (Greece), 1-4 November 2009, pp. 1-13 (in press).

Ganatsas P, Tsitsoni T, Tsakaldimi M, Zagas T (2011). Reforestation of degraded Kermes oak shrublands with planted pines: effects on vegetation cover, species diversity and community structure. New Forests 43 (1): 1-11. - doi: 10.1007/s11056-011-9262-z

Geomelas I, Verdi E, Kokla F (2007). Reforestation study of Mt Parnitha's fir forest. Prefecture of Attica, Department of Reforestations of Attica, Athens, Greece.

ISTA (2003). International rules for seed testing. International Seed Testing Association (ISTA). Seed Science and Technology 21: 160-186.

IPCC (2001). Climate change 2001: synthesis report. A Contribution of Working Groups I, II, and III to the Third Assessment Report of the Intergovernmental Panel on Climate Change (Watson RT, Core Writing Team eds). Cambridge University Press, Cambridge, UK, pp. 398.

MacMahon JA (1980). Ecosystems over time: succession and other types of change. In: "Forests: fresh perspectives from ecosystem analyses" (Waring R ed). Oregon State University Press, Corvallis, Oregon, USA, pp. 27-58.

Ne'eman G, Trabaud L (2000). Ecology, biogeography and management of Pinus halepensis and $P$. brutia. Forest ecosystems in the mediterranean basin. Backhuys Publishers, Leiden, The Netherlands, pp. 407.

Ocak A, Kurt L, Oz M, Tug GN (2007). Floristical and ecological studies on burned Black pine (Pinus nigra Arn.) forest area at Central Anatolia. Asian Journal of Plant Sciences 6: 892-905. doi: 10.3923/ajps.2007.892.905

Ordonez JL, Retana J, Espelta JM (2005). Effects of tee size, crown damage, and tree location on post-fire survival and cone production of Pinus nigra trees. Forest Ecology and Management 206: 109-117. - doi: 10.1016/j.foreco.2004. 10.067

Ordonez JL, Molowny-Horas R, Retana J (2006). A model of the recruitment of Pinus nigra from unburned edges after large wildfires. Ecological Modelling 197: 405-417. - doi: 10.1016/j.ecolmodel.2006.03.027

Panetsos C (1975). Monograph of Abies cephalonica Loudon. Annales Forestales (Zagreb) 7/1: $1-25$.
Parnitha National Park (2007). Web site. [online] URL: http://www.parnitha-np.gr/

Pausas JG, Ribeiro E, Vallejo R (2004). Post-fire regeneration variability of Pinus halepensis in the eastern Iberian peninsula. Forest Ecology and Management 203: 251-259. - doi: 10.1016/j.foreco.2004.07.061

Petropoulos GP, Vadrevu KP, Xanthopoulos G, Karantounias G, Scholze M (2010). A comparison of spectral angle mapper and artificial neural network classifiers combined with Landsat TM imagery analysis for obtaining burnt area mapping. Sensors 10: 1967-1985. - doi: 10.3390/ s100301967

Pickett STA, Collins SL, Armesto JJ (1987). Models, mechanisms and pathways of succession. The Botanical Review 53: 335-371. - doi: 10.1007/BF02858321

Politi PI, Arianoutsou M, Stamou GP (2009). Patterns of Abies cephalonica seedling recruitment in Mount Aenos national park, Cephalonia (Greece). Forest Ecology and Management 258: 1129-1136. - doi: 10.1016/j.foreco.2009.05.038 Politi P, Georghiou K, Arianoutsou M (2011). Reproductive biology of Abies cephalonica Loudon in Mount Aenos National park, Cephalonia (Greece). Trees - Structure and Function 25: 655-668 - doi: 10.1007/s00468-011-0542-1

Retana J, Espelta JM, Habrouk A, Ordonez JL, de la Sola-Morales F (2002). Regeneration patterns of three mediterranean pines and forest changes after a large wildfire in northeastern Spain. Ecoscience 9: 89-97.

Rodrigo A, Retana J, Pico FX (2004). Direct regeneration is not the only response of Mediterranean forests to large fires. Ecology 85: 716729. - doi: 10.1890/02-0492

Stamatopoulos I (1995). Regeneration of Abies cephalonica in Mountain Parnitha national park. PhD Thesis, Aristotle University of Thessaloniki, pp. 440. (in Greek with an English summary).

Thanos CA, Daskalakou E, Nikolaidou S (1996). Early post-fire regeneration of a Pinus halepensis forest on Mount Parnis, Greece. Journal of Vegetation Science 7: 273-280. - doi: $10.2307 / 3236328$

Trabaud L (1994). Post-fire plant community dynamics in the Mediterranean basin. In: "The role of fire in Mediterranean type ecosystems" (Moreno JM, Oechel WC eds). Ecological Studies, Springer-Verlag, vol. 107, pp. 1-15.

Tsopelas P, Angelopoulos A, Economou A, Soulioti N (2004). Mistletoe (Viscum album) in the fir forest of Mount Parnis, Greece. Forest Ecology and Management 202: 59-65. - doi: 10.1016/j.foreco.2004.06.032 